\title{
東精試験機シリーズ No.1
}

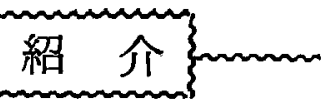

\section{T. S. S. 型恒温式応力緩和測定装置 (レラックスオメーター)}

目的

本機はゴム及びビニール等伸縮性のある材料の，恒温 に於ける一定伸びの応力緩和之時間の関係より，その材 料の特性を測定するすのであります.

原理

天科を応用したすので，Fig1に於いて，最初W と釣 合う，位置にWを置きます．Wを順次少くして行くこW す順次少くするか，若しくは距離を $\ell_{2}$ を短かくしなけ

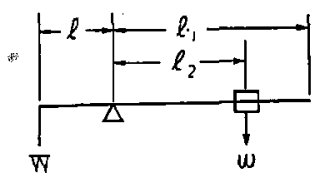

Fig 1

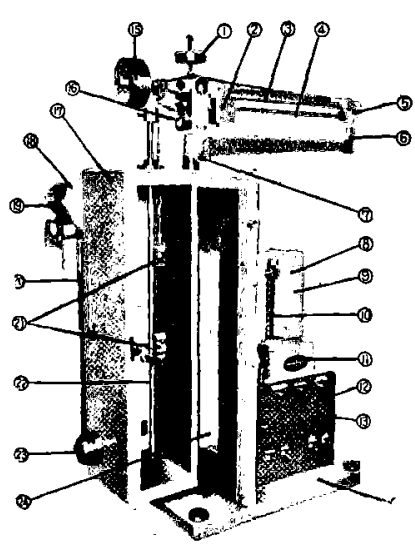

Fig 2

(17)恒 温 盙

(20)温 度·計

(18)ブロアー (21)千ャック (9)覮拌モーター 2支柱(目盛付き)

\section{構 造}

Fig 2 の写真のような構造で，支柱に天雬式の腕並び に恒温槽が取付けられております，腕はベアリングの支 点で支え，片方はチャック(21)，バランスウエイト(15)，他 方にはウエイト(2)，送りネジ(4)，モータ一(16)，並び水 銀接点(6)等が取付けられております。

バランスウエイトは, 何重の0位固を決める為にあり ます. ウエイトは, 最初応力に相当する位置に摠动させ バランスさせて置きますが，左右の均衡が破れますと， 接点より真空管リレーが墈き，モーターを回転させ，送 りネジに依って応力の減退に相当する荷重だけつつ移動 させます，恒温槽には，架気㩭拌用のブロアー，モータ 一, 温度調節用のバイメタル，ヒーター（断続, 継続共 に250W2 本)，並びに温度計が取付けられております。 又, 屝には嗄き空が取付けられ，試験中の試験片の状熊 を観察出来るようになつております。
記録装置には，前記ウエイト移動と同期に作動する送 りネジ(10，記録ペンめ，亚びに一定回転の記録円佮(9か 取付けられております。配電板には，シグナルランプ， パイロットランプ，電源, 摸拌用スイッチ，モータース 1ッチ，沚続，継続両電流用スイッチが取付けられ，函 内には，温度調節用りレー，並びにモータ一制衙用真空 管リレーが納められております。

試料

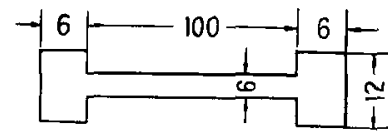

\section{使用方法}

先つ，試験前の各部調整として次の要領によって調節 致します．接点用の水銀が酸化する為時々取替える必要 がありますが，酸化を防ぐ為に，良質の植物油を少し浮 ぺて置きますと効果的です.

チャック間を決定するには，スケールで当り，丁度良 い所で指針(7及び水銀受けを䞨して水銀面を合せます。 水銀面を合せるには，モータースイッチを入れますとシ グナルランプが点威しますから，それで判定し，調節が 終りましたらスイッチは切って㯰きます，荷重の0位置 を決定するには，ウエイト(2)の指針を目盛0位置に置き 指針(7)が平均に振れるようにバランスウエイト(10在調節 して合せます。そ場合荷重が 2 殷階 $(0 \sim 900 \mathrm{~g}, 0 \sim 2700$ g)になっており，怪荷重の場合之重荷重の場合之は; バ ランスゥエイトの位置が違いますから，その都度合せる ように致します，温度調節は，㩭拌モータースイッチ並 びにヒータースイッチを入れ, 目的の温度にバイメタル で調節致します，一定温度に達しましたら，継続電流は 切り，継続電流だりに致します。（季節の寒暖により遠 いますか $120^{\circ} \mathrm{C}$ 位以上の場合は両電流共使用致します。)

以上の調整が終りましたら，試料をチャックに挾み， 伸びを与え，それに相当する位置までウエイトを搝動し 記録ペンを最上部まで持って来て，モータースイッチを 入れます，記録円筒は，ギヤに多少ギャップがあります

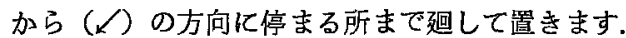

\section{注意事項}

(1) 送りネジは常にブラシ等で掃除し，マシン油を軽く 引いて㯰く。

(2) 水銀は，特々調べて酸化していたら取替え良質の植 物油を少し浮へて㯰く。

(a) 試験開始の時，ウエイト並に記録ペンの圐動部のッ マミを忘れないようにセットする。

(4) 温度の調節を行なう場合，温度に応じてヒーターの 容量を決める。

(可 チャック間距離は合っているか。（水銀を取替えた 時合せる)

(6) 荷重の容量を変えた場合は必ず 0 点の補正を行な う.（バランネウエイトを動かして合せる）

東洋精 機 製 作 所 